ORIGINAL ARTICLE

\title{
Chemotactic behavior of Campylobacter fetus subspecies towards cervical mucus, bovine placenta and selected substances and ion
}

\author{
Dionei Joaquim Haas ${ }^{1}$ (D) Jonata de Melo Barbieri ${ }^{1}$ (D), Elaine Maria Seles Dorneles ${ }^{2}$ (D), Andrey Pereira Lage ${ }^{{ }^{*}}$ (C) \\ ${ }^{1}$ Departamento de Medicina Veterinária Preventiva, Escola de Veterinária, Universidade Federal de Minas Gerais, Belo \\ Horizonte, MG, Brasil \\ ${ }^{2}$ Departamento de Medicina Veterinária, Universidade Federal de Lavras, Lavras, MG, Brasil
}

How to cite: Haas DJ, Barbieri JM, Dorneles EMS, Lage AP. Chemotactic behavior of Campylobacter fetus subspecies towards cervical mucus, bovine placenta and selected substances and ion. Anim Reprod. 2021;18(2):e20210008. https://doi.org/10.1590/1984-3143-AR2021-0008

\begin{abstract}
The chemotaxis of $C$. fetus subsp. venerealis and $C$. fetus subsp. fetus was determined in the presence of bovine cervical mucus and bovine placental extract. Some reported substances and ion in those materials, such amino acids, ferrous iron, hormones, sugars and organic acids were also investigated. Bovine cervical mucus, bovine placenta extracts and some substances and ion of these materials namely L-fucose, L-aspartate, L-glutamate, L-serine, ferrous iron, fumarate, pyruvate and succinate were chemoattractants. The chemottraction was significantly larger in higher concentrations of the tested substances and ion and significant differences among tested strains were also observed. Meso-erythritol and hormones bovine placental lactogen, $17 \beta$-estradiol, and progesterone did not elicit chemotactical response. In conclusion, this chemotactic behavior may guide the $C$. fetus navigation in the bovine host's genital tract and be an important cofactor of tissue tropism for this bacterium.
\end{abstract}

Keywords: bacterial chemotaxis, chemoattractants, tissue tropism, bovine genital tract, bovine genital campylobacteriosis.

\section{Introduction}

C. fetus subsp. venerealis and C. fetus subsp. fetus are important cause of reproductive disorders in cattle. C. fetus subsp. fetus causes sporadic abortions and C. fetus subsp. venerealis the bovine genital campylobacteriosis (BGC), a venereal disease that causes early embryonic death, resulting in high rates of return to estrous, at longer and irregular cycles, and, to a lesser frequency, abortions (Alves et al., 2011; Sahin et al., 2017; Balzan et al., 2020; Haas et al., 2020). Therefore, large economic losses occur due to decrease production of milk and calves, increase calving interval, and large number of open cows at the end of the breeding season (McCool et al., 1988; Pellegrin et al., 2002).

Despite this great impact on animal health, the mechanisms involved in the pathogenesis of infection of the two C. fetus subspecies in cattle, especially regarding to tissue tropism, remains elusive. The clinical signs observed suggest that $C$. fetus subsp. venerealis has a strong tropism for bovine genital tract, reaching the bovine uterus via ascending route, while $C$. fetus subsp. fetus shows marked tropism to uterus during pregnancy, reaching the placenta by translocation from its intestinal habitat (Vargas et al., 2002; Sahin et al., 2017; Silveira et al., 2018; Farace et al., 2019; Balzan et al., 2020). Therefore, it has been speculated that tissue tropism of $C$. fetus subspecies is dictated by the presence of local substrates, as amino acids, 
organic acids, sugars, iron and hormones (Walsh et al., 1973; Ware, 1980; Mshelia et al., 2007; Giobergia et al., 2019; Balzan et al., 2020), which could be potentially attractants to bacteria and chemotaxis-guide to bacterial movements.

Chemotaxis enables bacteria to move according to chemical gradients, which allows them to adapt better to their natural habitats via moving toward favorable conditions and away from hostile surroundings, affords key physiological benefits, including enhanced access to growth substrates (Porter et al., 2011; Bi and Sourjik, 2018; Korolik, 2019). Another important implication of chemotaxis is that it also plays an important role in infection and disease, since it enables bacteria to find suitable colonization sites and maintain their preferred niches (Matilla and Krell, 2018; Yang and Ottemann, 2019). As this is required for optimal host infection and pathogenicity, chemotaxis have been shown to be important for the initiation of the several diseases (Porter et al., 2011; Johnson and Ottemann, 2018; Matilla and Krell, 2018), including those caused by Campylobacter species, as C. jejuni (Korolik, 2019). For C. jejuni infection, chemotaxis is an important prerequisite for host colonization and pathogenesis, which could also be linked to niche specificity (Lertsethtakarn et al., 2011; Chandrashekhar et al., 2017; Korolik, 2019).

Orthologues proteins of the chemotaxis signal transduction pathway has been observed in C. fetus (Fahmy et al., 2012), including C. fetus subsp. fetus ATCC $27374^{\top}$ (NCTC 10842 ${ }^{\top}$ ); and C. fetus subsp. venerealis ATCC $19438^{\top}$ (NCTC 10354') type strains (Stynen et al., 2011; Oliveira et al., 2016). The chemosensory receptors TIps (TIp1, TIp3, TIp4, TIp6-8, Tlp10 and CetB), the methyltransferase CheR and the methylesterase CheB, the histidine kinase CheA, the scaffolds proteins CheW/V, the phosphatase CheZ, and the response regulator CheY, that ultimately acts on the flagellar motor to switch rotation either clockwise or counterclockwise (Bren and Eisenbach, 2000; Korolik, 2019), were identified. In a proteomic study, our group observed that Tlp and CheW proteins of $C$. fetus subsp. venerealis are significantly upregulated during infection of the genital tract of heifers (Stynen, 2009; Stynen et al., 2009). These genomic and proteomic evidences point that $C$. fetus probably use chemotaxis to reach particular milieu and to the possible participation of chemotaxis in host infection by $C$. fetus.

Since information on the $C$. fetus chemotaxis to substances and structures of bovine genital tract can help to understand and elucidate events related to tissue tropism, niche adaptation and pathogenesis of BGC, we investigated the chemotactic response of $C$. fetus subsp. venerealis and $C$. fetus subsp. fetus towards cervical mucus, bovine placenta and some of reported substances and ion of bovine cervical mucus and bovine placenta.

\section{Material and methods}

\section{Bacterial strains and growth conditions}

Four $C$. fetus strains were used in this study (Table 1): the type strain of the $C$. fetus subsp. venerealis, ATCC $19438^{\top}$ (NCTC 10354'); the type strain of the species C. fetus, $C$. fetus subsp. fetus ATCC $27374^{\top}$ (NCTC 10842 ${ }^{\top}$ ); the host-passaged strain C. fetus subsp. venerealis P3 (P3) (Stynen, 2009; Haas et al., 2019) and isolate C. fetus subsp. fetus EV-5 (EV-5) (Leite, 1977). The P3 strain was the $C$. fetus subsp. venerealis ATCC $19438^{\top}$ strain recovered from cervical mucus after three serial passages in virgin heifers (Stynen, 2009; Haas et al., 2019).

Table 1. Campylobacter fetus strains used in chemotaxis assays.

\begin{tabular}{cccc} 
Strains & Subspecies & Origin & Reference \\
${\text { ATCC } 19438^{\top}}^{\text {PTC }}$ & venerealis & bovine cervical mucus & ATCC \\
\hline PTC & venerealis & bovine cervical mucus & Stynen, 2009; Haas et al., 2019 \\
\hline EV-5 & fetus & brain of sheep fetus & ATCC \\
\hline ATCC & fetus & aborted bovine fetus & Leite, 1977 \\
\hline
\end{tabular}

ATCC - American Type Culture Collection. * P3 - It is a C. fetus subsp. venerealis reference strain (ATCC $19438^{\top}=$ NCTC $\left.10354^{\top}\right)$, recovered after three serial passages in virgin heifers (Stynen, 2009; Haas et al., 2019). 
Stock cultures in thioglycolate broth containing $20 \%$ glycerol at $-80{ }^{\circ} \mathrm{C}$ were inoculated in blood agar (Brain Heart Infusion (BHI) (Merck, Germany), 1.5\% of bacteriological agar (Himedia, India) and $5 \%$ defibrinated horse blood) at $37{ }^{\circ} \mathrm{C}$ under microaerophilic conditions $\left(5 \% \mathrm{O}_{2}, 10 \% \mathrm{CO}_{2}\right.$ and $\left.85 \% \mathrm{~N}_{2}\right)$ for 36 hours and subcultured, under the same conditions, twice prior to the chemotaxis assays. To avoid potential alterations due to laboratory passage, P3 strain was subcultured no more than three times. The purity of the cultures was routinely checked by visualizing the morphology of the colonies and, microscopically, by fuchsin staining.

\section{Cervical mucus and placenta extract and sample design}

All biological material and tissues were collected under the Brazilian legislation on animal experimentation (Brasil, 2016) from animals in an abattoir under federal inspection service (SIF).

The placentas were obtained from three pregnant bovine uteruses with estimated pregnancy age of 110, 120 and 140 days, according to the crown-rump (CR) lengths of each fetus, 21, 25 and $33 \mathrm{~cm}$, respectively, based on the methodology of Evans and Sack (1973). The mean age of the fetuses used was therefore 123.33 days, which corresponds to a mean age of 4.11 months of pregnancy. The time was selected since in the cow it is the period in which the majority of abortions by C. fetus occurs (Mshelia et al., 2007; Silveira et al., 2018). Intercotiledonary chorioallantoic membrane and fetal cotyledons were placed in phosphate buffered saline (PBS) (0.01 M, pH 7.0, all from Merck, Germany) (1:2) (w/v), macerated aseptically, and centrifuged at $1000 \times g$ for 5 minutes at $4{ }^{\circ} \mathrm{C}$ temperature to remove large tissue fragments. The resultant supernatants were collected and mixed (pool) for use in chemotaxis assays.

Mucus was obtained from of the cervicovaginal region from three cows in stage I of estrous cycle (days 1 to 4 of the estrous cycle). The stage of the estrous cycle was estimated according to the methodology of Ireland et al. (1980). Mucus samples were diluted in PBS $(1: 2)(\mathrm{w} / \mathrm{v})$ and mixed (pool) for use in chemotaxis assays. Mucus and placenta samples were confirmed free of $C$. fetus by multiplex PCR (Hum et al., 1997) before being used in the chemotaxis assays.

\section{Substances and ion}

Substances and ion from the metabolite class of previously reported components of bovine mucus and placenta metabolome (Ware, 1980; Igwebuike, 2006; Will et al., 2010; Dolgorsuren et al., 2017; Tríbulo et al., 2019) and that simultaneously combine energy-chemotactic potential were selected for investigation. In particular, the amino acids L- aspartate, L-glutamate and L-serine, the organic acids fumarate, pyruvate and succinate, the ion ferrous iron, the sugars meso-erythritol and L-fucose and the hormones bovine placental lactogen, $17 \beta$-estradiol, and progesterone were tested. The tested concentration ranges of these substances and ion, and their preparations, were based on previous studies of Campylobacter spp. growth and chemotaxis (Walsh et al., 1973; Ware, 1980; Hugdahl et al., 1988; Hazeleger et al., 1998; Vegge et al., 2009; Burrough et al., 2012) and in the concentrations reported in genital tract of the bovine female (Pope et al., 1982; Henricks et al., 1983; Inaba et al., 1983; Elhassan et al., 2001; Alvarez-Oxiley et al., 2007; Dolgorsuren et al., 2017), to mimic the physiological range found by the bacteria in the host. Information on all tested substances and ion is listed in Table 2. Amino acids, organic acids, L-fucose, ferrous iron, meso- erythritol and deoxycholic acid were prepared in PBS (Walsh et al., 1973; Hugdahl et al., 1988; Vegge et al., 2009), bovine placental lactogen was diluted in ultrapure water (AlvarezOxiley et al., 2007) while 17ß-estradiol and progesterone were dissolved in dimethyl sulfoxide (DMSO) (Sigma-Aldrich, USA) and then diluted to desired concentrations in PBS (Burrough et al., 2012). All substances were sterilized by filtration on $0.45 \mu \mathrm{m}$ filter (Merck, Germany) before their use. 
Table 2. Substances, ion and concentrations tested in chemotaxis assays of Campylobacter fetus.

\begin{tabular}{|c|c|c|c|}
\hline Chemical tested & Concentrations tested & Diluent & Source \\
\hline Bovine cervical mucus* & $1: 2 \mathrm{w} / \mathrm{v}$ & PBS & Cows in estrus \\
\hline $\begin{array}{l}\text { Bovine intercotiledonary chorioallantoic } \\
\text { membrane extract }{ }^{\star *}\end{array}$ & $1: 2 \mathrm{w} / \mathrm{v}$ & PBS & Bovine placenta \\
\hline Bovine fetal cotyledons extract ${ }^{\star \star}$ & $1: 2 \mathrm{w} / \mathrm{v}$ & PBS & Bovine placenta \\
\hline \multicolumn{4}{|l|}{ Substances and ion } \\
\hline L-aspartate & $0.01,0.1$ and $1 \mathrm{M}$ & PBS & Sigma-Aldrich $^{1}$ \\
\hline L-glutamate & $0.01,0.1$ and $1 \mathrm{M}$ & PBS & Sigma-Aldrich \\
\hline L-serine & $0.01,0.1$ and $1 \mathrm{M}$ & PBS & Sigma-Aldrich \\
\hline Fumarate (sodium) & $0.01,0.1$ and $1 \mathrm{M}$ & PBS & Sigma-Aldrich \\
\hline Pyruvate (sodium) & $0.01,0.1$ and $1 \mathrm{M}$ & PBS & Sigma-Aldrich \\
\hline Succinate (sodium) & $0.01,0.1$ and $1 \mathrm{M}$ & PBS & Sigma-Aldrich \\
\hline Ferrous iron (sulphate) & $0.01,0.1$ and $1 \mathrm{M}$ & PBS & Merck $^{2}$ \\
\hline Meso-erythritol & $0.01,0.1$ and $1 \mathrm{M}$ & PBS & Sigma-Aldrich \\
\hline Bovine placental lactogen & $0.05,0.5,5$ and $50 \mathrm{ng} / \mathrm{mL}$ & $\mathrm{H}_{2} \mathrm{O}^{3}$ & ProspecBio 4 \\
\hline $17 \beta$-estradiol & $0.05,0.5,5$ and $50 \mathrm{ng} / \mathrm{mL}$ & ${\mathrm{DMSO} / \mathrm{PBS}^{5}}^{5}$ & Sigma-Aldrich \\
\hline Progesterone & $\begin{array}{l}0.05,0.5,5,25,50,100 \\
\text { and } 200 \mathrm{ng} / \mathrm{mL}\end{array}$ & DMSO/PBS & Sigma-Aldrich \\
\hline \multicolumn{4}{|l|}{ Controls } \\
\hline Deoxycholic acid (chemorepellent) & $0.1 \mathrm{M}$ & PBS & Merck \\
\hline PBS pH 7.0 (nonchemotactic) & $0.01 \mathrm{M}$ & PBS & - \\
\hline L-fucose (chemoattractant) & $0.1 \mathrm{M}$ & PBS & Sigma-Aldrich \\
\hline
\end{tabular}

1 - Sigma-Aldrich, USA; 2 - Merck, Germany; 3 - Ultrapure water, USA; 4 - ProspecBio; 5 - DMSO, Dimethyl sulfoxide/ PBS, phosphate-buffered saline. *Obtained from of the cervicovaginal region from three cows in stage I of estrous cycle (days 1 to 4 of the estrous cycle). **Obtained from bovine pregnant uterus at gestational age between 110 to 140 days.

\section{Chemotaxis assays}

Chemotactic assays were performed using the disk method on soft agar (Vegge et al., 2009) modified by Tareen et al., (2010) as follows. C. fetus strains were grown on blood agar (Hazeleger et al., 1998; Tareen et al., 2010; Burrough et al., 2012; Elgamoudi et al., 2018) at $37{ }^{\circ} \mathrm{C}$ under microaerophilic conditions for 36 hours, suspended in PBS, adjusted spectrophotometrically $\left(\mathrm{OD}_{600}\right)$ to approximately $8 \times 10^{9}$ viable $\mathrm{CFU} / \mathrm{mL}$ and after mixed $(1: 2)(\mathrm{v} / \mathrm{v})$ with tempered $\left(42^{\circ} \mathrm{C}\right)$ soft agar $(0.8 \%$ bacteriological agar; Himedia, India) (Tareen et al., 2010) to obtain the test condition of $4 \times 10^{9}$ viable CFU/mL in PBSsoft (0.4\%) agar (Vegge et al., 2009). The number of viable bacteria in each bacterial suspension measured by turbidimetry was confirmed, retrospectively, by the drop counting method (Miles et al., 1938). This method was previously validated for counting C. fetus (Haas et al., 2019).

Afterwards, $12 \mathrm{~mL}$ of the bacterial soft agar suspension was poured into a $9 \mathrm{~cm}$ diameter Petri dish. Then, sterile filter discs (diameter $=6 \mathrm{~mm}$ ) (Laborclin, Brazil), soaked with $50 \mu \mathrm{L}$ of the test substance (Table 2), were placed on the semi-solidified agar (Vegge et al., 2009; Tareen et al., 2010). PBS (0.01 M, pH 7.0), L-fucose $(0.1 \mathrm{M})$ and deoxycholic acid $(0.1 \mathrm{M})$ were used as nonchemotactic, chemoattractant and chemorepellent controls, respectively, based on studies of chemotaxis of $C$. jejuni (Hugdahl et al., 1988; Vegge et al., 2009; Tareen et al., 2010; Dwivedi et al., 2016) and results of a pre-experiment carried with $C$. fetus strains (data not shown). Following 4 hours of incubation at $37^{\circ} \mathrm{C}$ under microaerophilic conditions, chemotactic activity was examined over an indirect light source. Bacterial accumulations or clearing zones around a disc were interpreted as zones of attraction toward chemoattractant or repulsion from chemorepellent, respectively (Vegge et al., 2009; Tareen et al., 2010). (Figure 1). The diameter of chemotaxis halos was measured in millimeters $(\mathrm{mm})$. The absence of both, accumulation or repulsion in the region around a disc, was interpreted as no response and the substance was classified as nonchemotactic substance (Hugdahl et al., 1988; Vegge et al., 2009; Tareen et al., 2010). (Figure 1). The chemotaxis assays were performed twice for each strain and each concentration of chemical tested (Hugdahl et al., 1988). 


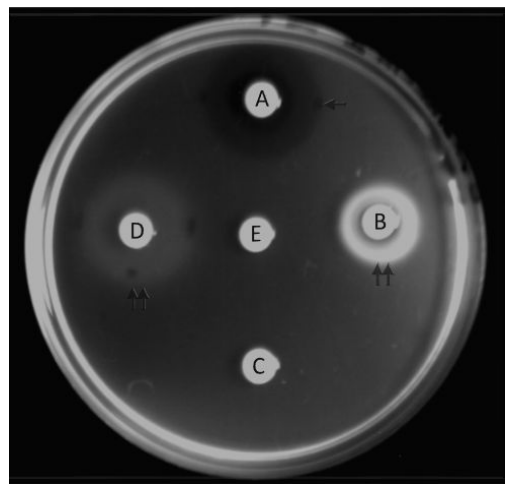

Figure 1. Chemotaxis assays with Campylobacter fetus subsp. venerealis P3 strain mixed in PBS-soft (0.4\%) agar. Filter discs adsorbed with $50 \mu \mathrm{L}$ of investigated substances and ion were placed on the semi-solidified bacterial suspension, and migration zones (halos) were measured after $4 \mathrm{~h}$ of incubation under microaerophilic conditions. (A) $0.1 \mathrm{M}$ deoxycholic acid (chemorepellent; around the disc is a clear zone surrounded by a ring of bacteria that were driven away); (B) $0.1 \mathrm{M}$ ferrous iron (chemoattractant; bacterial accumulation around the disc); (C) progesterone $50 \mathrm{ng} / \mathrm{mL}$ (nonchemotactic; no response is observed); (D) L - fucose $0.1 \mathrm{M}$ (chemoattractant); (E) PBS $0.01 \mathrm{M}$ (nonchemotactic control). Arrows point to border of each zone of bacterial accumulation (double arrows) or repulsion (single arrows). C. fetus subsp. venerealis P3 is a C. fetus subsp. venerealis reference strain (ATCC $19438^{\top}=$ NCTC $10354^{\top}$ ), recovered after three serial passages in virgin heifers (Stynen, 2009; Haas et al., 2019).

\section{Statistical analysis}

The statistical analysis and graphs were performed using the $R$ software ( $R$ version 4.0.3, R Development Core Team, New Zealand) (R Core Team, 2020). For the comparisons among bacterial strains in cervical mucus, intercotiledonary chorioallantoic membrane and fetal cotyledons ANOVA was used, followed by Tukey test (Zar, 1996). The same analysis was also used for the comparisons among bacterial strains and concentrations for the same chemical substance. Besides, the different concentrations of the chemical substance were analyzed by linear regression (Zar, 1996). The differences were considered statistically significant when $\mathrm{P}<0.05$.

\section{Results}

The controls L-fucose, deoxycholic acid and PBS were attractant, repellant and nonchemotactic, respectively, as expected to all C. fetus strains tested (Figure 2).

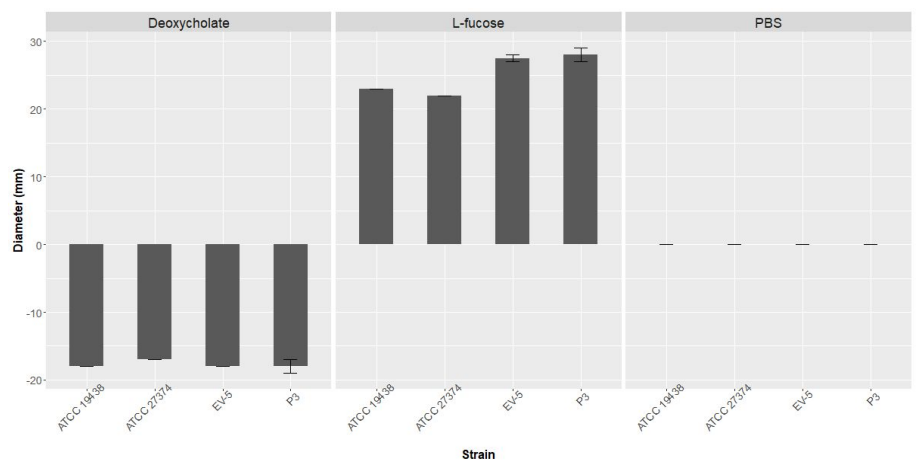

Figure 2. Chemotaxis of Campylobacter fetus by deoxycholic acid $(0.1 \mathrm{M})$, L-fucose $(0.1 \mathrm{M})$ and PBS $(0.01 \mathrm{M}$, $\mathrm{pH}$ 7.0), used as chemorepellent, chemoattractant and nonchemotactic controls, respectively. The columns show halo diameter size (in millimeters) of chemotaxis. ATCC $19438^{\top}-C$. fetus subsp. venerealis reference strain; P3 - C. fetus subsp. venerealis reference strain $\left(\right.$ ATCC $19438^{\top}=$ NCTC $10354^{\top}$ ) recovered after three serial passages in virgin heifers (Stynen, 2009; Haas et al., 2019); ATCC 27374T - C. fetus subsp. fetus reference strain; EV-5 - C. fetus subsp. fetus strain isolated of bovine abortion (Leite, 1977).

Bovine cervical mucus was chemoattractant to all C. fetus strains evaluated, and no statistical difference was observed among the tested strains (Figure 3). 


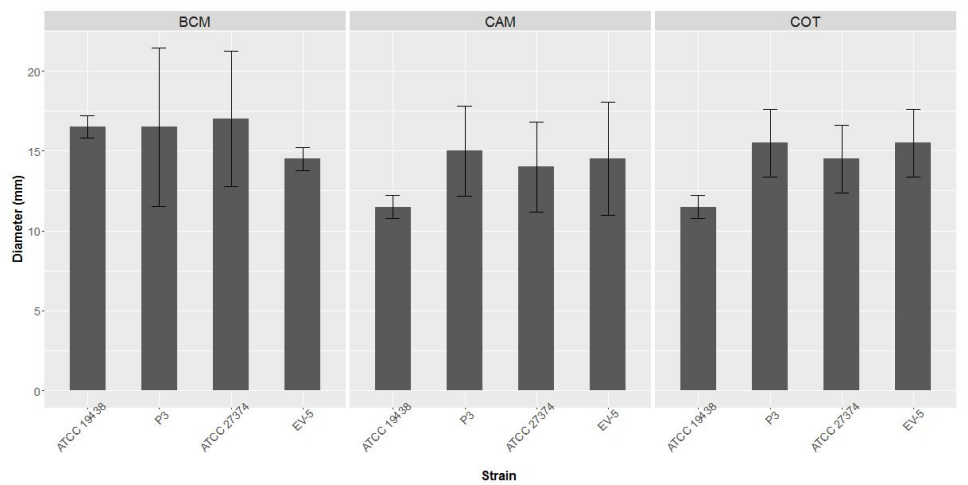

Figure 3. Chemotaxis of Campylobacter fetus by bovine cervical mucus (BCM), intercotiledonary chorioallantoic membrane (CAM) and bovine cotyledon (COT) extract. The columns show halo diameter size (in millimeters) of chemoattraction. BCM was obtained of three cows in stage I of estrous cycle (days 1 to 4 of the estrous cycle) and diluted in PBS (1:2) $(\mathrm{w} / \mathrm{v})$. The placentas were obtained from three pregnant cows with gestational age between 110 to 140 days and macerated in PBS (1:2) (w/v). ATCC $19438^{\top}-$ C. fetus subsp. venerealis reference strain; P3 - C. fetus subsp. venerealis reference strain (ATCC $19438^{\top}=$ NCTC 10354 ), recovered after three serial passages in virgin heifers (Stynen, 2009; Haas et al., 2019); ATCC $27374^{\top}-$ C. fetus subsp. fetus reference strain; EV-5 - C. fetus subsp. fetus strain isolated from bovine abortion (Leite, 1977). Bars show standard error. There was no statistical difference among the strains for the mucus nor the placental extracts.

Bovine intercotiledonary chorioallantoic membrane and fetal cotyledons extracts were chemoattractant to C. fetus subsp. venerealis and C. fetus subsp. fetus, however, no statistical differences among the tested strains were observed (Figure 3).

The substances and ion L-aspartate, L-glutamate, L-serine, pyruvate, succinate, fumarate, and ferrous iron, were chemoattractant to all C. fetus strains evaluated, being the halos significantly larger and visually denser in higher concentrations of the tested substances (Figure 4 and 5). Regression analysis revealed that the increase in chemoattraction was significantly higher as concentration increases. The $\mathrm{R}^{2}$, the variance explained by model, was greater than $95 \%$ for all attractive substances and ion, except for L-serine, which still presented a high $\mathrm{R}^{2}(86 \%)$, but lower than the others.

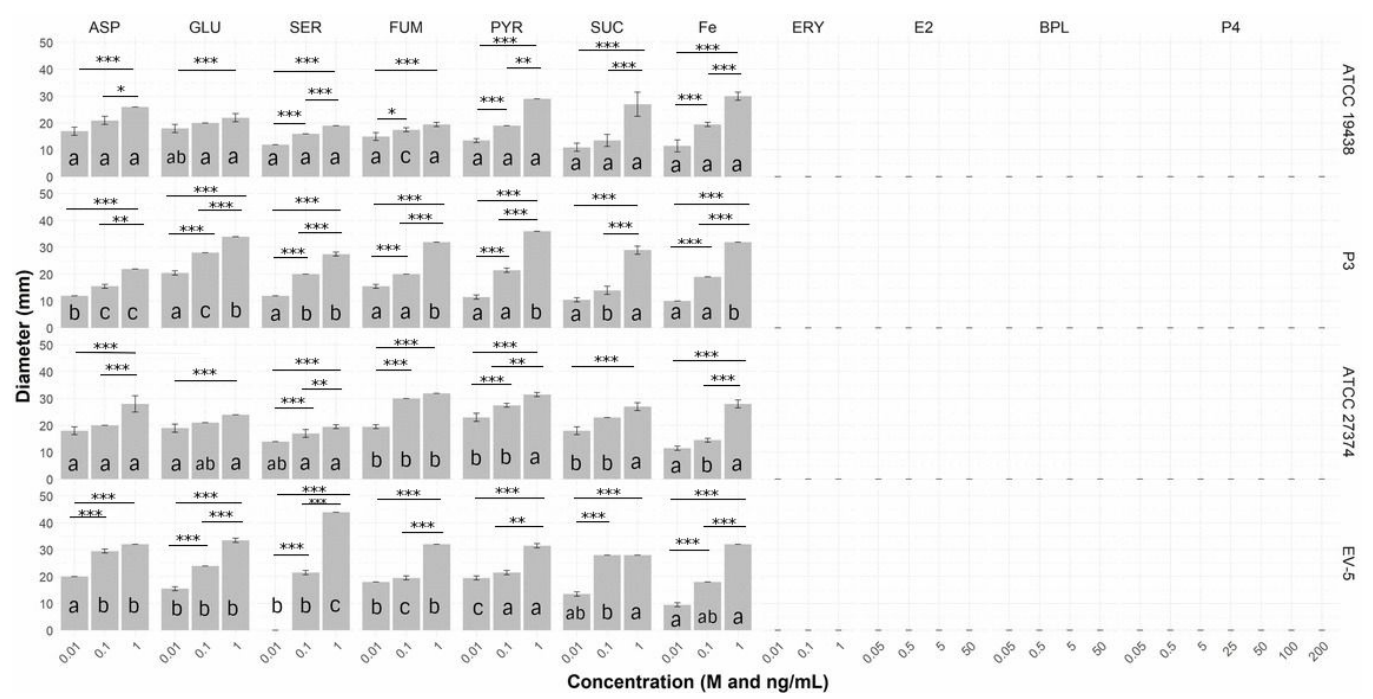

Figure 4. Chemotaxis behavior of Campylobacter fetus to reported substances and ions of bovine cervical mucus and substances produced by bovine placenta. The columns show halo diameter size (in millimeters) of chemoattraction. L-aspartate (ASP), L-glutamate (GLU), L-serine (SER), fumarate (FUM), pyruvate (PYR), succinate (SUC) ferrous iron (Fe), meso-erythritol (ERY) concentrations is in molar (M). The $17 \beta$-estradiol (E2), bovine placental lactogen (BPL) and progesterone (P4) concentrations is in ng/mL. ATCC $19438^{\top}-C$. fetus subsp. venerealis reference strain; $\mathrm{P3}-$ C. fetus subsp. venerealis reference strain $\left(\mathrm{ATCC} 19438^{\top}=\mathrm{NCTC} 10354^{\top}\right.$ ) recovered after three serial passages in virgin heifers (Stynen, 2009; Haas et al., 2019); ATCC $27374^{\top}-$ C. fetus subsp. fetus reference strain; EV-5 - C. fetus subsp. fetus strain isolated of bovine abortion (Leite, 1977). Bars show standard error. ${ }^{*} \mathrm{P}<0.05 ;{ }^{*} \mathrm{P}<0.01 ;{ }^{*} * \mathrm{P}<0.001$ indicate levels of significant statistical difference between concentrations in the same substance in the same strain. Different lowercase letters within the same substance and concentration reflect significant statistical difference among bacterial strains. 


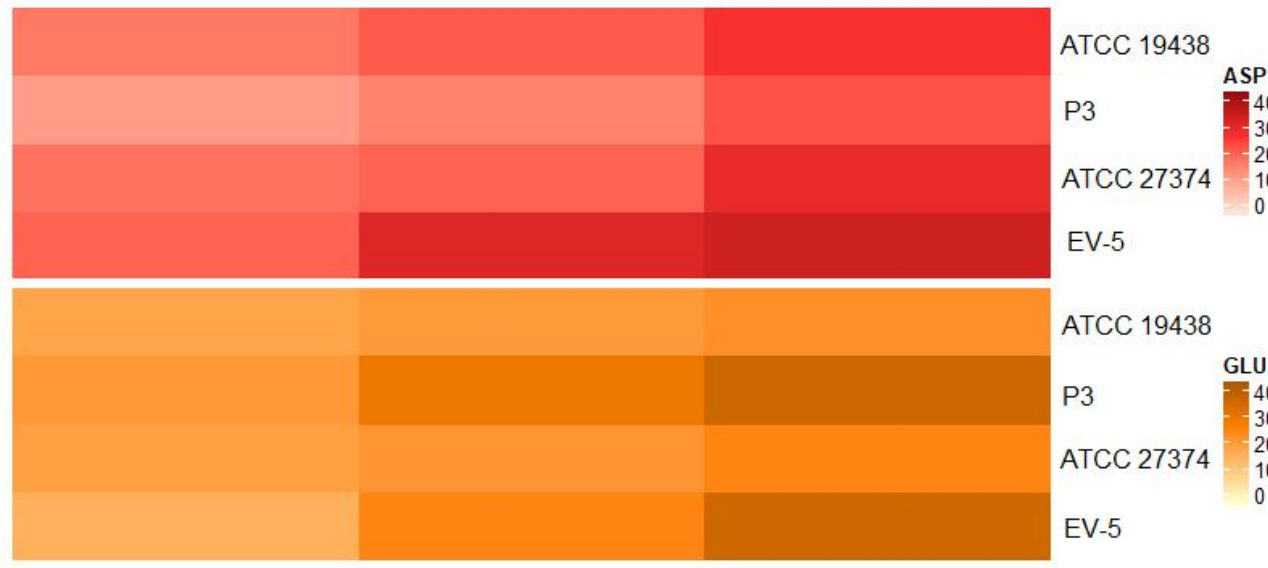

ATCC 19438
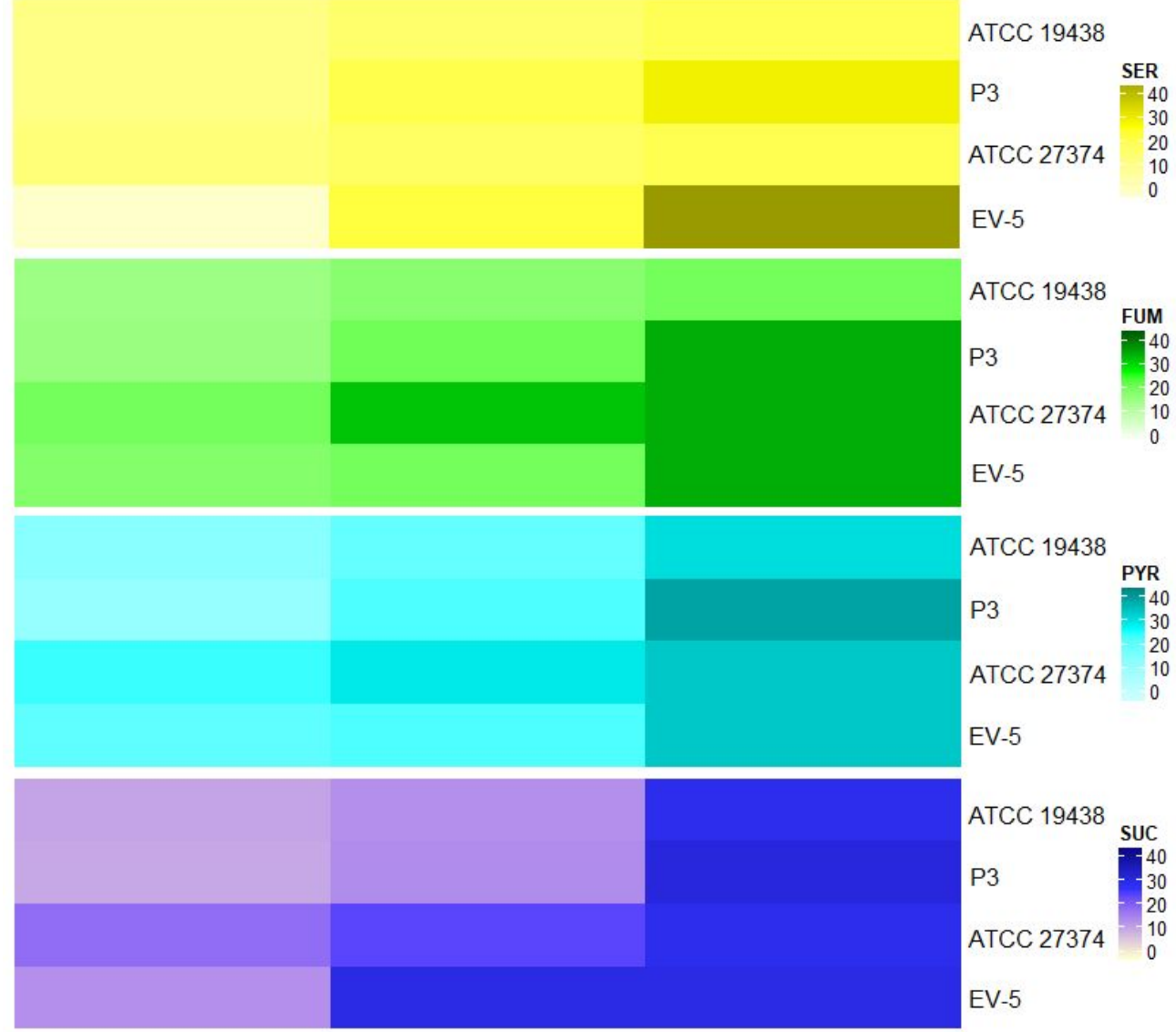

ATCC 19438
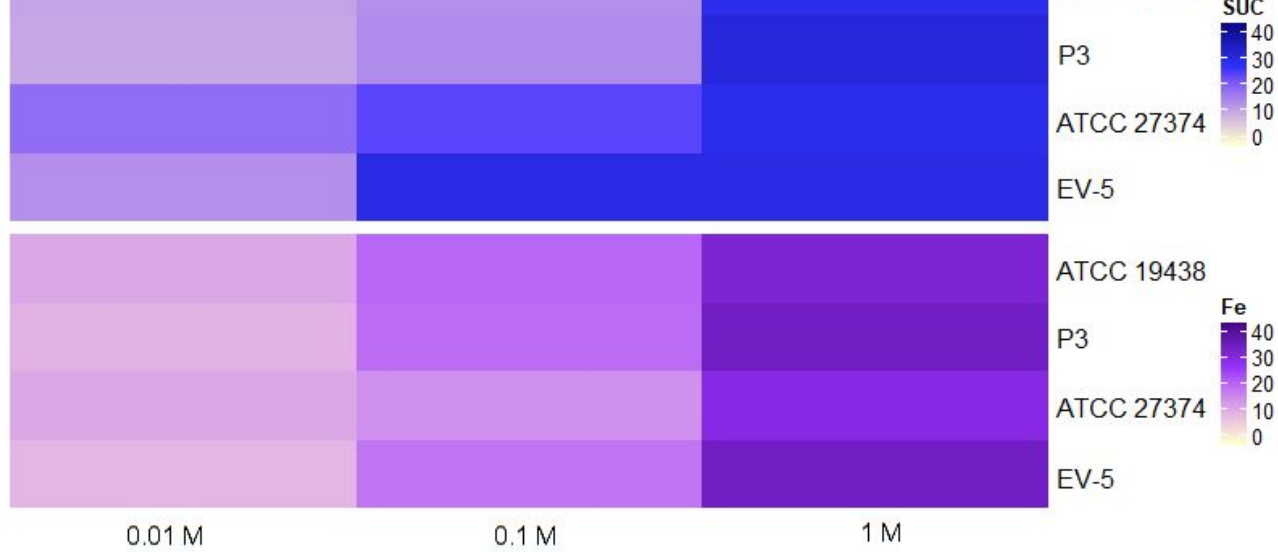

Figure 5. Heatmap of the chemoattractive substances and ion for the investigated Campylobacter fetus strains. ASP - L-aspartate, GLU - L-glutamate, SER - L-serine, FUM - fumarate, PYR - pyruvate, SUC - succinate, $\mathrm{Fe}$ - ferrous iron. ATCC $19438^{\top}-$ C. fetus subsp. venerealis reference strain; P3 - C. fetus subsp. venerealis reference strain $\left(\right.$ ATCC $19438^{\top}=$ NCTC $10354^{\top}$ ) recovered after three serial passages in virgin heifers (Stynen, 2009; Haas et al., 2019); ATCC $27374^{\top}$ - C. fetus subsp. fetus reference strain; EV-5 - C. fetus subsp. fetus strain isolated of bovine abortion (Leite, 1977). Regression analysis revealed that the increase in chemoattraction was significantly higher as concentration increases. The $\mathrm{R}^{2}$, the variance explained by model, was greater than $95 \%$ for all attractive substances and ion, except for L-serine, which still presented a high $\mathrm{R}^{2}(86 \%)$, but lower than the others. 
The chemoattraction haloes of P3 strain for L-glutamate, L-serine, fumarate, pyruvate, and ferrous iron was significantly higher compared with that observed for C. fetus subsp. venerealis ATCC $19438^{\top}$ parental strain. In contrast, C. fetus subsp. venerealis ATCC $19438^{\top}$ strain showed greater chemoattraction halos for L-aspartate than P3 strain. The chemoattraction of the EV- 5 strain for L- aspartate, L-glutamate, L-serine was significantly higher when compared with that observed for C. fetus subsp. fetus ATCC $27374^{\top}$ strain. C. fetus subsp. fetus ATCC $27374^{\top}$ strain showed greater chemoattraction halos for fumarate and pyruvate than the three strains of bovine origin, $C$. fetus subsp. venerealis ATCC 19438' ${ }^{\top}$, C. fetus subsp. venerealis P3 and C. fetus subsp. fetus EV-5.

Meso-erythritol, bovine placental lactogen, $17 \beta$-estradiol and progesterone were nonchemotactic to all C. fetus strains investigated.

\section{Discussion}

Chemotaxis is cell movement in response to chemical cues employed by bacterial pathogens to migrate towards environments that are better for growth. Consequently contributes to these microorganisms to reach their preferred host niches, being an important subject of tissue tropism (Porter et al., 2011; Johnson and Ottemann, 2018; Matilla and Krell, 2018; Korolik, 2019; Yang and Ottemann, 2019). In the present study, we report the chemotactic behavior of reproductive pathogen C. fetus towards cervical mucus, bovine placenta and some reported substances and ion of bovine cervical mucus and bovine placenta, which brings an insight on the use of chemotaxis by $C$. fetus to reach their preferred colonization niches and the tissue tropism of this bacterium.

Penetration and survive in mucus layer, guided by chemotaxis, is an essential step during the colonization of mucous surfaces by motile bacteria, favoring the establishment of bacterial populations in this environment (Alemka et al., 2012; Yang and Ottemann, 2019). In this context, attraction to mucus during the estrus, period in which the infection occurs, is a very relevant finding to the $C$. fetus pathogenesis in genital tract of the bovine female, since the bacterium is able to remain in the genital tract by successfully colonizing the mucus layer (Ware, 1980; Balzan et al., 2020). This ability of campylobacters to colonize the mucus is facilitated by its spiral cell shape that creates a corkscrew-like rotation, by the swimming behavior (flagellar motility) (Blaser et al., 2008; Balzan et al., 2020) and probably by chemotaxis, which guides the environmental navigation in this viscous layer. The biological significance of mucus chemotaxis may be that it increases nutrient acquisition efficiency and enhance the known ability of $C$. fetus to metabolize amino acids and organic acids within the mucus (Ware, 1980; Blaser et al., 2008), favoring bacterial multiplication in the genital tract of cows. In fact, in the presence of bovine cervical mucus, the respiratory activity of $C$. fetus is increased, evidenced by higher the rates of oxygen uptake (Ware, 1980), suggesting the use of these substrates as carbon source. This assumption corroborates the findings for the reported components of the mucus investigated, where it was observed that the chemical constituents that elicited a positive chemotactic response (Figure 3 ) are the main sources of energy for $C$. fetus. They are metabolic substrates (L- aspartate, L-glutamate, and L-serine), electron donors (pyruvate and succinate) and electron acceptors (fumarate) (Blaser et al., 2008). These evidences show that $C$. fetus swims towards substrates for which is possible to obtain energy from oxidative phosphorylation and tricarboxylic acid cycle. Positive chemotaxis for these amino acids and organic acids suggests that these substances and ion may be involved in chemotaxis for cervical mucus, since they are the main energy sources for $C$. fetus and are among the most abundant components of bovine cervical mucus (Ware, 1980; Elhassan et al., 2001; Tríbulo et al., 2019). Indeed, positive chemotactic response to amino acids and organic acids may facilitate bacterial penetration on mucus layer, favoring the survival and colonization of mucosal surfaces.

C. fetus attraction to L-fucose is a particularly interesting observation and may have direct relevance in vivo, since fucose is a terminal sugar in the mucins of the genital tract of the cow (Pluta et al., 2011) and serves as binding target for campylobacters to the mucosal epithelium (Dwivedi et al., 2016). This ability to sense fucose could drives the microorganism towards a chemical gradient of fucose in the genital environment and mediate the binding of $C$. fetus to fucosylated structures from epithelium, which are important target sites for colonization. 
Other mucin glycans, such galactose and N-acetylgalactosamine, have been suggested as potential binding sites for C. fetus subsp. venerealis in the uterus of heifers (Cipolla et al., 1998).

In addition, this L-fucose taxis may also be associated to use of sugar as source of carbon, as it occurs with $C$. jejuni strains that have the genetic locus (fuc locus) that encode pathways for fucose uptake/metabolism and are able to catabolize fucose (Dwivedi et al., 2016). In $C$. fetus, the genes encoding the fucose transporter FucP and the enzymes required to degrade fucose, are also present, predicting that $C$. fetus may be able to metabolize L-fucose (Stynen et al., 2011; Oliveira et al., 2016), however, the operability of the pathway and the fucose metabolism of $C$. fetus were not evaluated.

Our results regarding ferrous iron clearly showed that this substrate is a powerful attractant to $C$. fetus, which could be related to the central role that the iron has in essential metabolic processes. Iron is a cofactor for proteins involved of cellular metabolism, enzyme catalysis, and sensing extracellular and intracellular signals (Chandrashekhar et al., 2018). The sensing and navigation of $C$. fetus towards ferrous iron may be mediated by FeoAB system, a predicted system in the genome of C. fetus subsp. venerealis, including ATCC $19438^{\top}$ strain (Stynen et al., 2011) and believed to carry the environmental ferrous iron across the outer membrane by porins and through the cytoplasmic membrane, by transporter proteins FeoA and FeoB (Naikare et al., 2006; Blaser et al., 2008). The movement towards the ferrous iron, as observed for amino acids, organic acids and fucose, probably also has an important role in the pathogenesis of BGC, because can enhance the uptake and use of this essential nutrient. The uptake of ferrous iron in large amounts is a crucial event for the success of infection and is a determinant of colonization for C. jejuni (Naikare et al., 2006; Chandrashekhar et al., 2018). Interestingly, the chemoattraction zones were larger in higher concentrations of ferrous iron, amino acids, and organic acids (Figure 3), clearly showing that $C$. fetus navigates further towards environments with higher concentrations of these substances.

Differences are reported when comparing host-passaged strains with laboratory-adapted reference strains (Stynen, 2009; Haas et al., 2019) and it was also observed in our past and present studies. For example, heifer-passaged C. fetus subsp. venerealis induced higher expression of CXCL8 chemokine by HeLa cells than the parental C. fetus subsp. venerealis reference strain ATCC 19438' (Haas et al., 2019). The significantly greater attraction of the $C$. fetus subsp. venerealis P3 strain to several of the investigated substances (glutamate, serine, fumarate, pyruvate, and ferrous iron) compared to C. fetus subsp. venerealis reference parental strain ATCC $19438^{\top}$ suggests that the passage in the host increased chemotactic capacity of $C$. fetus subsp. venerealis $\mathrm{P} 3$ strain and that this group of substances can be very important during host infection. In contrast, the reduced chemotaxis of the C. fetus subsp. venerealis P3 strain when compared with the reference $C$. fetus subsp. venerealis strain ATCC $19438^{\top}$ suggests that aspartate would be less important during in vivo infection. The globally reduced chemotactic profile of $C$. fetus subsp. venerealis laboratory-adapted ATCC $19438^{\top}$ strain probably results from laboratory subculture over time, that is known to cause a general loss of virulence, including decrease chemotactic motility related genes/proteins expression in campylobacters (Stynen, 2009; Cooper et al., 2013; King et al., 2013). Thus, the higher chemotactic activity of C. fetus subsp. fetus EV-5 strain for aspartate, glutamate, and serine, when compared with the C. fetus subsp. fetus ATCC $27374^{\top}$ reference strain may be due to fact that the EV-5 strain has fewer subcultures compared with the ATCC $27374^{\top}$ strain. We should also consider the possible influence of the differences in origin of the strains, as C. fetus subsp. fetus EV-5 is a bovine isolate while $C$. fetus subsp. fetus ATCC $27374^{\top}$ is an ovine isolate. C. fetus subsp. fetus ATCC $27374^{\top}$ strain showed significantly higher chemotaxis to organic acids (fumarate, pyruvate, and succinate) when compared to the three strains of bovine origin, C. fetus subsp. fetus EV-5, C. fetus subsp. venerealis ATCC $19438^{\top}$ and C. fetus subsp. venerealis $\mathrm{P} 3$.

Tropism for placental tissues is a frequent phenomenon in C. fetus infection (Vargas et al., 2002; Sahin et al., 2017; Farace et al., 2019) and an important step in the pathogenesis of BGC, since it enhances the access of large numbers of bacterial cells to the placenta and thereby influences the course of infection. Our in vitro findings indicate that $C$. fetus uses chemotaxis in vivo to reach the placenta and infects the tissue with large numbers of bacterial cells, which may be important for rapid bacterial establishment and to lead to abortion. This dynamics of 
bacterial navigation through the genital tract can be also influenced by the animal immune status, being facilitated and accelerated in non-immune animals or, on the other hand, made it more difficult and delayed due to the action of the immune response to previously $C$. fetus infected animals. Therefore, our results of $C$. fetus attraction to intercotiledonary chorioallantoic membrane and fetal cotyledon from the second gestational trimester could also partially explain why the majority of abortions due to $C$. fetus infection are mostly noted at 4 to 6 months of pregnancy in BGC (Mshelia et al., 2007; Sahin et al., 2017; Silveira et al., 2018).

Our findings also indicate the presence of chemotactic factors for $C$. fetus in bovine placenta. The bovine placental trophoblast is an exuberant producer of erythritol, 17 $\beta$-estradiol, placental lactogen and, especially, progesterone (Igwebuike, 2006; Nguyen et al., 2012; Letesson et al., 2017). However, in our assays, at physiological level concentrations that simulate the host environment, all of these substances were nonchemotactic for $C$. fetus, as bacteria do not respond chemotatically to these individual substances.

The non-chemotactic behavior of $C$. fetus to erythritol possibly stems from the absence of a catabolic pathway, such as that found in Brucella abortus, which allows the metabolism of erythritol and has been implicated in placental tropism by B. abortus (Letesson et al., 2017). Like erythritol sugar, failure of placental lactogen, which is produced only during pregnancy by binucleate placenta cells (Alvarez-Oxiley et al., 2007), and estradiol, which is produced in substantial amounts by the trophoblast (Inaba et al., 1983; Nguyen et al., 2012), to stimulate chemotactic response to $C$. fetus suggest that both hormones also did not guide the swimming of $C$. fetus towards the bovine placenta. In addition, this inert behavior by estradiol means that ovarian estradiol from the estrous follicular phase may have no effect on the $C$. fetus taxis during estrus, at which stage infection transmission and vaginal colonization occurs.

The chemotactic effects of progesterone were of particular interest, as bovine high levels of progesterone in the uterus in the luteal phase of the reproductive cycle (Pope et al., 1982) and the increased placental synthesis of progesterone in the second trimester of pregnancy (Nguyen et al., 2012), which could explain, in part, the ascension of $C$. fetus to the uterus and the occurrence of abortions during this period. However, the absence of chemotaxis towards progesterone, at levels that mimic its estrous cycle and pregnancy concentrations, indicate that C. fetus is not responding chemotactically to progesterone and suggest that this hormone does not drives the rise of the bacterium to the uterus and placenta.

The fact that the placenta extract elicits chemotactic response in $C$. fetus, but reported hormones (placental lactogen, $17 \beta$-estradiol and progesterone) and erythritol did not, suggests that the attraction $C$. fetus by placental extract could have occurred due to the presence of other placental components, such as amino acids. Amino acids are abundant in this tissue, as previously reported (Dolgorsuren et al., 2017) and were strong chemoattractants to $C$. fetus in the study. In addition, we must also consider that one or more placental components, which were not evaluated in the present study, may be involved in the chemoattraction of $C$. fetus by bovine placenta.

\section{Conclusion}

In conclusion, $C$. fetus exhibits chemotaxis towards bovine cervical mucus and placenta extracts as well as some substances and ion reported in these materials, such as amino acids, ferrous iron, fucose and organic acids. This chemotactic behavior may guide the $C$. fetus navigation in host and be an important subject of tropism for placenta and bovine female genital tract.

\section{References}

Alemka A, Corcionivoschi N, Bourke B. Defense and adaptation: the complex inter-relationship between Campylobacter jejuni and mucus. Front Cell Infect Microbiol. 2012;2:15.

http://dx.doi.org/10.3389/fcimb.2012.00015. PMid:22919607. 
Alvarez-Oxiley AV, Sousa NM, Hornick JL, Touati K, van der Weijden GC, Taverne MA, Szenci O, Sulon J, Debliquy P, Beckers JF. Radioimmunoassay of bovine placental lactogen using recombinant and native preparations: determination of fetal concentrations across gestation. Reprod Fertil Dev. 2007;19(7):877-85. http://dx.doi.org/10.1071/RD06173. PMid:17897591.

Alves TM, Stynen APR, Miranda KL, Lage AP. Campilobacteriose genital bovina e tricomonose genital bovina: epidemiologia, diagnóstico e controle. Pesq Vet Bras. 2011;31(4):336-44. http://dx.doi.org/10.1590/S0100-736X2011000400011.

Balzan C, Ziech RE, Gressler LT, Vargas APC. Bovine genital campylobacteriosis: main features and perspectives for diagnosis and control. Cienc Rural. 2020;50(3):e20190272. http://dx.doi.org/10.1590/0103-8478cr20190272.

Bi S, Sourjik V. Stimulus sensing and signal processing in bacterial chemotaxis. Curr Opin Microbiol. 2018;45:22-9. http://dx.doi.org/10.1016/j.mib.2018.02.002. PMid:29459288.

Blaser MJ, Newell DG, Thompson SA, Zechner EL. Pathogenesis of Campylobacter fetus. In: Nachamkin I, Szymanski C, Blaser MJ, editors. Campylobacter. 3rd ed. Washington, DC.: ASM Press; 2008. p. 401-28. http://dx.doi.org/10.1128/9781555815554.ch23.

Brasil. Ministério da Ciência, Tecnologia e Inovações. Conselho Nacional de Controle de Experimentação Animal CONCEA. Resolução Normativa $n^{\circ}$ 30, de 2 de fevereiro de 2016. Baixa a Diretriz Brasileira para o Cuidado e a Utilização de Animais em Atividades de Ensino ou de Pesquisa Científica - DBCA. Diário Oficial da União [Internet], Brasília, 3 fev. 2016. Seção 1, p. 3. 2017 [cited 2021 Feb 9]. Available on: https://antigo.mctic.gov.br/mctic/export/sites/institucional/institucional/concea/arquivos/legislacao/resoluco es_normativas/Resolucao-Normativa-CONCEA-n-30-de-02.02.2016-D.O.U.-de-03.02.2016-Secao-I-Pag.-03.pdf

Bren A, Eisenbach M. How signals are heard during bacterial chemotaxis: protein-protein interactions in sensory signal propagation. J Bacteriol. 2000;182(24):6865-73. http://dx.doi.org/10.1128/JB.182.24.6865-6873.2000. PMid:11092844.

Burrough ER, Wu Z, Sahin O, Zhang Q, Yaeger MJ. Spatial distribution of putative growth factors in the guinea pig placenta and the effects of these factors, plasma, and bile on the growth and chemotaxis of Campylobacter jejuni. Vet Pathol. 2012;49(3):470-81. http://dx.doi.org/10.1177/0300985811424755. PMid:22081135.

Chandrashekhar K, Kassem II, Rajashekara G. Campylobacter jejuni transducer like proteins: chemotaxis and beyond. Gut Microbes. 2017;8(4):323-34. http://dx.doi.org/10.1080/19490976.2017.1279380. PMid:28080213.

Chandrashekhar K, Srivastava V, Hwang S, Jeon B, Ryu S, Rajashekara G. Transducer-like protein in Campylobacter jejuni with a role in mediating chemotaxis to iron and phosphate. Front Microbiol. 2018;9:2674. http://dx.doi.org/10.3389/fmicb.2018.02674. PMid:30505293.

Cipolla AL, Paolicchi FA, Poso MA, Morsella CG, Casaro AP, Massone AR, Villegas R, Callejas S, Gimeno EJ. Lectin-binding sites in uterus and oviduct of normal and Campylobacter fetus subspecies venerealisinfected heifers. Eur J Histochem EJH. 1998;42(1):63-70. PMid:9615192.

Cooper KK, Cooper MA, Zuccolo A, Joens LA. Re-sequencing of a virulent strain of Campylobacter jejuni NCTC11168 reveals potential virulence factors. Res Microbiol. 2013;164(1):6-11. http://dx.doi.org/10.1016/j.resmic.2012.10.002. PMid:23046762.

Dolgorsuren T, Lkhagvasuren N, Batsaikhan D, Enkh-Oyun T, Enkhtuya P. Biochemical and pharmacological study of biologically active preparation of placenta. Int J Pharm Sci Invent. [serial on the Internet]. 2017 [cited 2021 Feb 9];6(2):4-7. Available from: http://www.ijpsi.org/Vol6(2).html

Dwivedi R, Nothaft H, Garber J, Xin Kin L, Stahl M, Flint A, van Vliet AH, Stintzi A, Szymanski CM. L-fucose influences chemotaxis and biofilm formation in Campylobacter jejuni. Mol Microbiol. 2016;101(4):57589. http://dx.doi.org/10.1111/mmi.13409. PMid:27145048.

Elgamoudi BA, Ketley JM, Korolik V. New approach to distinguishing chemoattractants, chemorepellents and catabolised chemoeffectors for Campylobacter jejuni. J Microbiol Methods. 2018;146:83-91. http://dx.doi.org/10.1016/j.mimet.2018.02.008. PMid:29428740.

Elhassan YM, Wu G, Leanez AC, Tasca RJ, Watson AJ, Westhusin ME. Amino acid concentrations in fluids from the bovine oviduct and uterus and in KSOM-based culture media. Theriogenology. 2001;55(9):1907-18. http://dx.doi.org/10.1016/S0093-691X(01)00532-5. PMid:11414495.

Evans HE, Sack WO. Prenatal development of domestic and laboratory mammals: growth curves, external features and selected references. Zentralbl Veterinarmed C. 1973;2(1):11-45. http://dx.doi.org/10.1111/j.1439-0264.1973.tb00253.x. PMid:4745140. 
Fahmy D, Day CJ, Korolik V. Comparative in silico analysis of chemotaxis system of Campylobacter fetus. Arch Microbiol. 2012;194(2):57-63. http://dx.doi.org/10.1007/s00203-011-0754-1. PMid:21983836.

Farace PD, Morsella CG, Cravero SL, Sioya BA, Amadio AF, Paolicchi FA, Gioffré AK. L-cysteine transporterPCR to detect hydrogen sulfide-producing Campylobacter fetus. Peer]. 2019;7:e7820. http://dx.doi.org/10.7717/peerj.7820. PMid:31720099.

Giobergia M, Herrera M, Teruel M, Riccio B, Catena M. Histopathologic characterization of the reproductive organs of heifers experimentally infected with Campylobacter fetus venerealis. Rev Colomb Cienc Pecu. 2019;33(3):149-58. http://dx.doi.org/10.17533/udea.rccp.v33n1a05.

Haas DJ, Cottorello ACP, Alves TM, Dorneles EMS, Stynen APR, Morais-Rios PA G, Machado MM, Miranda $\mathrm{KL}$, Araújo BS, Lage AP. Adherence to and chemokine expression in HeLa cells infected by Campylobacter fetus subsp. venerealis. EC Vet Sci. [serial on the Internet]. 2019 [cited 2021 Feb 9];4(1):4-14. Available from: https://www.ecronicon.com/veterinary-science.php

Haas DJ, Miranda-Guimarães KL, Dorneles EMS, Lage AP. Prevalence of Bovine Genital Campylobacteriosis in beef cattle in Brazil. EC Vet Sci. [serial on the Internet]. 2020 [cited 2021 Feb 9];5(12):42-53. Available from: https://www.ecronicon.com/ecve/ECVE-05-00316.php

Hazeleger WC, Wouters JA, Rombouts FM, Abee T. Physiological activity of Campylobacter jejuni far below the minimal growth temperature. Appl Environ Microbiol. 1998;64(10):3917-22. http://dx.doi.org/10.1128/AEM.64.10.3917-3922.1998. PMid:9758819.

Henricks DM, Gray SL, Hoover JL. Residue levels of endogenous estrogens in beef tissues. J Anim Sci. 1983;57(1):247-55. http://dx.doi.org/10.2527/jas1983.571247x. PMid:6885662.

Hugdahl MB, Beery JT, Doyle MP. Chemotactic behavior of Campylobacter jejuni. Infect Immun. 1988;56(6):1560-6. http://dx.doi.org/10.1128/iai.56.6.1560-1566.1988. PMid:3372020.

Hum S, Quinn K, Brunner J, On SL. Evaluation of a PCR assay for identification and differentiation of Campylobacter fetus subspecies. Aust Vet J. 1997;75(11):827-31. http://dx.doi.org/10.1111/j.1751 0813.1997.tb15665.x. PMid:9404619.

Igwebuike UM. Trophoblast cells of ruminant placentas - A minireview. Anim Reprod Sci. 2006;93(34):185-98. http://dx.doi.org/10.1016/j.anireprosci.2005.06.003. PMid:16043315.

Inaba T, Oka A, Koketsu Y, Nakama S, Imori T. Progesterone and estrogen synthesis by the bovine Placenta. Jpn J Anim Reprod. 1983;29(2):88-93. http://dx.doi.org/10.1262/jrd1977.29.88.

Ireland JJ, Murphee RL, Coulson PB. Accuracy of predicting stages of bovine estrous cycle by gross appearance of the corpus luteum. J Dairy Sci. 1980;63(1):155-60. http://dx.doi.org/10.3168/jds.S00220302(80)82901-8. PMid:7372895.

Johnson KS, Ottemann KM. Colonization, localization, and inflammation: the roles of $H$. pylori chemotaxis in vivo. Curr Opin Microbiol. 2018;41:51-7. http://dx.doi.org/10.1016/j.mib.2017.11.019. PMid:29202336.

King RM, Day CJ, Hartley-Tassell LE, Connerton IF, Tiralongo J, McGuckin MA, Korolik V. Carbohydrate binding and gene expression by in vitro and in vivo propagated Campylobacter jejuni after immunomagnetic separation. J Basic Microbiol. 2013;53(3):240-50. http://dx.doi.org/10.1002/jobm.201100466. PMid:22753110.

Korolik V. The role of chemotaxis during Campylobacter jejuni colonisation and pathogenesis. Curr Opin Microbiol. 2019;47:32-7. http://dx.doi.org/10.1016/j.mib.2018.11.001. PMid:30476739.

Leite RC. Avaliação de alguns métodos de diagnóstico e análise custo/benefício do controle da campilobacteriose bovina [dissertation]. Belo Horizonte: Universidade Federal de Minas Gerais; 1977. Portuguese. [cited 2021 Feb 9]. Available from: https://repositorio.ufmg.br/handle/1843/BUOS 8QVK6E?mode=full

Lertsethtakarn P, Ottemann KM, Hendrixson DR. Motility and chemotaxis in Campylobacter and Helicobacter. Annu Rev Microbiol. 2011;65(1):389-410. http://dx.doi.org/10.1146/annurev-micro090110-102908. PMid:21939377.

Letesson J-J, Barbier T, Zúñiga-Ripa A, Godfroid J, De Bolle X, Moriyón I. Brucella Genital Tropism: what's on the Menu. Front Microbiol. 2017;8:506. http://dx.doi.org/10.3389/fmicb.2017.00506. PMid:28400761.

Matilla MA, Krell T. The effect of bacterial chemotaxis on host infection and pathogenicity. FEMS Microbiol Rev. 2018;42(1). http://dx.doi.org/10.1093/femsre/fux052. PMid:29069367. 
McCool CJ, Townsend MP, Wolfe SG, Simpson MA, Olm TC, Jayawardhana GA, Carney JV. Prevalence of bovine venereal disease in the Victoria River District of the Northern Territory: likely economic effects and practicable control measures. Aust Vet J. 1988;65(5):153-6. http://dx.doi.org/10.1111/j.17510813.1988.tb14445.x. PMid:3401162.

Miles AA, Misra SS, Irwin JO. The estimation of the bactericidal power of the blood. J Hyg (Lond). 1938;38(6):732-49. PMid:20475467.

Mshelia GD, Singh J, Amin JD, Woldehiwet Z, Egwu GO, Murray RD. Bovine venereal campylobacteriosis: an overview. Perspect Agric Vet Sci Nutr Nat Resour. 2007;2(080). http://dx.doi.org/10.1079/PAVSNNR20072080.

Naikare H, Palyada K, Panciera R, Marlow D, Stintzi A. Major role for FeoB in Campylobacter jejuni ferrous iron acquisition, gut colonization, and intracellular survival. Infect Immun. 2006;74(10):5433-44. http://dx.doi.org/10.1128/IAl.00052-06. PMid:16988218.

Nguyen PTT, Conley AJ, Soboleva TK, Lee RSF. Multilevel regulation of steroid synthesis and metabolism in the bovine placenta. Mol Reprod Dev. 2012;79(4):239-54. http://dx.doi.org/10.1002/mrd.22021. PMid:22431389.

Oliveira LM, Resende DM, Dorneles EM, Horácio EC, Alves FL, Gonçalves LO, Tavares GS, Stynen AP, Lage AP, Ruiz JC. Complete genome sequence of type strain Campylobacter fetus subsp. fetus ATCC 27374. Genome Announc. 2016;4(6):e01344-16. http://dx.doi.org/10.1128/genomeA.01344-16. PMid:27979934.

Pellegrin AO, Lage AP, Sereno JRB, Ravaglia E, Costa MS, Leite RC. Bovine genital campylobacteriosis in Pantanal, State of Mato Grosso do Sul, Brazil. Rev Délevage Médecine Vét Pays Trop. 2002;55(3):16973. https://doi.org/10.19182/remvt.9820.

Pluta K, Irwin JA, Dolphin C, Richardson L, Fitzpatrick E, Gallagher ME, Reid CJ, Crowe MA, Roche JF, Lonergan P, Carrington SD, Evans AC. Glycoproteins and glycosidases of the cervix during the periestrous period in cattle. J Anim Sci. 2011;89(12):4032-42. http://dx.doi.org/10.2527/jas.2011-4187. PMid:21803974.

Pope WF, Maurer RR, Stormshak F. Distribution of progesterone in the uterus, broad ligament, and uterine arteries of beef cows. Anat Rec. 1982;203(2):245-50. http://dx.doi.org/10.1002/ar.1092030206. PMid:7114497.

Porter SL, Wadhams GH, Armitage JP. Signal processing in complex chemotaxis pathways. Nat Rev Microbiol. 2011;9(3):153-65. http://dx.doi.org/10.1038/nrmicro2505. PMid:21283116.

R Core Team. R: A language and environment for statistical computing [Internet]. Vienna, Austria: R Foundation for Statistical Computing; 2020. Version 4.0.3 Bunny-Wunnies Freak Out. [cited 2021 Feb 9]. Available from: https://www.r-project.org/

Sahin O, Yaeger M, Wu Z, Zhang Q. Campylobacter-associated diseases in animals. Annu Rev Anim Biosci. 2017;5(1):21-42. http://dx.doi.org/10.1146/annurev-animal-022516-022826. PMid:27860495.

Silveira CS, Fraga M, Giannitti F, Macías-Rioseco M, Riet-Correa F. Diagnosis of bovine genital campylobacteriosis in South America. Front Vet Sci. 2018;5:321. http://dx.doi.org/10.3389/fvets.2018.00321. PMid:30619902.

Stynen AP, Lage AP, Moore RJ, Rezende AM, de Resende VD, Ruy PC, Daher N, Resende DM, de Almeida SS, Soares SC, de Abreu VA, Rocha AA, dos Santos AR, Barbosa EG, Costa DF, Dorella FA, Miyoshi A, de Lima AR, Campos FD, de Sá PG, Lopes TS, Rodrigues RM, Carneiro AR, Leão T, Cerdeira LT, Ramos RT, Silva A, Azevedo V, Ruiz JC. Complete genome sequence of type strain Campylobacter fetus subsp. venerealis NCTC 10354T. J Bacteriol. 2011;193(20):5871-2. http://dx.doi.org/10.1128/JB.05854-11. PMid:21952544.

Stynen APR, Ferreira LRP, Chung J, Shenckman S, Lage AP. Identification of proteins of Campylobacter fetus subsp. venerealis differentially expressed before and after infection in heifer by mass spectrometry. In: Proceedings of the 15th International Workshop on Campylobacter, Helicobacter, and related organisms - CHRO; 2009; Niigata, Japan; 2009.

Stynen APR. Expressão diferencial de proteínas de amostras de Campylobacter fetus subsp. venerealis após passagens sucessivas em novilhas [thesis]. Belo Horizonte: Universidade Federal de Minas Gerais; 2009. Portuguese. [cited 2021 Feb 9]. Available from: https://repositorio.ufmg.br/handle/1843/SMOC-9HCNTH

Tareen AM, Dasti JI, Zautner AE, Groß U, Lugert R. Campylobacter jejuni proteins Cj0952c and Cj0951c affect chemotactic behaviour towards formic acid and are important for invasion of host cells. Microbiology. 2010;156(10):3123-35. http://dx.doi.org/10.1099/mic.0.039438-0. PMid:20656782. 
Tríbulo P, Balzano-Nogueira L, Conesa A, Siqueira LG, Hansen PJ. Changes in the uterine metabolome of the cow during the first 7 days after estrus. Mol Reprod Dev. 2019;86(1):75-87. http://dx.doi.org/10.1002/mrd.23082. PMid:30383328.

Vargas AC, Costa MM, Vainstein MH, Kreutz LC, Neves JP. Campylobacter fetus subspecies venerealis surface array protein from bovine isolates in Brazil. Curr Microbiol. 2002;45(2):111-4. http://dx.doi.org/10.1007/s00284-001-0090-9. PMid:12070688.

Vegge CS, Brøndsted L, Li Y-P, Bang DD, Ingmer H. Energy taxis drives Campylobacter jejuni toward the most favorable conditions for growth. Appl Environ Microbiol. 2009;75(16):5308-14. http://dx.doi.org/10.1128/AEM.00287-09. PMid:19542337.

Walsh AF, White FH, Warnick AC. The effects of erythritol, FSH and female gonadal hormones on the growth in vitro of Vibrio fetus var. venerealis. J Reprod Fertil. 1973;32(3):465-71. http://dx.doi.org/10.1530/jrf.0.0320465. PMid:4692342.

Ware DA. Pathogenicity of Campylobacter fetus subsp. venerealis in causing infertility in cattle. Br Vet J. 1980;136(3):301-3. http://dx.doi.org/10.1016/S0007-1935(17)32297-2. PMid:7388595.

Will S, Rici R, Miglino MA, Antunes A. Trace element of bovine placenta: histological analysis and distribution maps using $\mu S X R F$. In: Méndez-Vilas A, Díaz J, editors. Microscopy: science, technology, applications and education [Internet]. Badajoz: Formatex Res Cent. 2010 [cited 2021 Feb 9]. p. 103946. Available from: https://www.yumpu.com/en/document/read/21047297/trace-element-of-bovineplacenta-formatex-research-center

Yang C, Ottemann KM. Control of bacterial colonization in the glands and crypts. Curr Opin Microbiol. 2019;47:38-44. http://dx.doi.org/10.1016/j.mib.2018.11.004. PMid:30502720.

Zar JH. Bioestatistical analysis. 3rd ed. New Jersey: Prentice Hall; 1996.

\section{Author contributions}

DJH: conceptualization, data curation, formal analysis, investigation, methodology, project administration, validation, visualization, writing - original draft, writing - review \& editing; JMB: data curation, formal analysis, software, validation, visualization, writing - original draft; EMSD: validation, visualization, writing - original draft, writing - review \& editing; APL: conceptualization, formal analysis, funding acquisition, methodology, project administration, resources, supervision, validation, visualization, writing - original draft, writing - review \& editing. 